\title{
ハイブリッド土石流モデルによる平成15年 水俣市集川の土石流に関する再現計算 NUMERICAL SIMULATION OF THE DEBRIS FLOW AT THE ATSUMARI RIVER, MINAMATA CITY, 2003
}

\author{
里深好文 ${ }^{1}$ \\ Yoshifumi SATOFUKA \\ 1正会員 工博 京都大学助教授 農学研究科森林科学専攻（广 $606-8502$ 京都市左京区北白川追分町）
}

\begin{abstract}
A severe debris flow disaster occurred at the Atsumari river, Minamata city, in July2003. The origin of the debris flow is considered as a large scale landslide caused by heavy rainfall. The soil block produced by a landslide run out to the downstream area with liquification.

I apply 2-D hybrid debris flow model to the debris flow disaster. It was proposed to explain the runoff process of the soil block including the fluidization phenomenon, which is composed of the usual two-dimensional debris flow model and a tracking model for soil block movement as solid.

The model can reproduce the debris flow disaster. The rate of the fluidization strongly affects to the runoff process. The peak discharge becomes big due to the concentration of soil blocks at the front part of the debris flow. If the unsaturated part in the soil block becomes larger, the block can not continue to flow, and it forms a natural dam.
\end{abstract}

Key Words : Landslide, debris flow, liquefied soil block, two dimensional numerical simulation

\section{1.はじめに}

平成15年7月20日午前4時20分ごろ，熊本県水俣市宝川 内集地区において, 斜面崩壊を起源とする土石流が発生 し，死者15名，住家全半壊14棟の被害が生じた。山腹斜 面の崩壊を起因とする土石流には，天然ダムの形成・破 壊を伴うものと, 崩壊土砂がそのまま流動化するものと があるといわれているが，7月末に行った著者らの現地 調査によれば，今回の土石流は後者のタイプであると考 えられる。

1997年に鹿児島県出水市の針原川において発生した土 石流点,2) も, 今回と同じタイプであったとされており， この災害を契機として著者らは崩壊土砂が土石流化する メカニズムについて研究3をを進め, 数值シミュレーショ ンモデルの開発を行ってきた。このモデルは有限差分法 による土石流の2次元汇濫堆積モデルと, 土塊の運動を ラグランジュ的に解析する手法とを組み合わせたもので, 水路実験への適用を通じてその有用性が確かめられてい る。以後, このモデルを2-D hybrid debris flow mode1 (2次元ハイブリッド土石流モデル) と呼ぶ。

本研究ではこのモデルを宝川内の事例に適用し，大き な被害が生じた原因等について考察する。なお，河床堆 積物が存在しない場合でもこのような災害が生じ得るこ とを示すため, 河床の流動化に関しては無視している。

\section{2. 宝川内集地区で発生した土石流災害の概要}

土木学会調査団の速報によると土石流発生時刻（4時

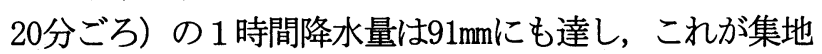
区の約 $1.7 \mathrm{~km}$ 上流の地点における斜面崩壊を生じさせた としている。図-1に土石流が流下した集川周辺の地形図 を示す。この地形図の作成にあたり, アジア航測(株)が ホームページ上で公開している土石流発生直後の $1 \mathrm{~m}$ 間隔 等高線図を使用させていただいた。この等高線図は航空 機レーザー計測による1mDEMデータに基づいており，こ のような高精度の情報が迅速に得られるようになったこ とは大きな進歩であるといえよう。本研究ではこの等高 線図から $10 \mathrm{~m}$ メシュの地形データを読み取り, 解析に 用いている。また，この図に示した土石流の流下範囲も アジア航測(株)のデータに基づいたものである。

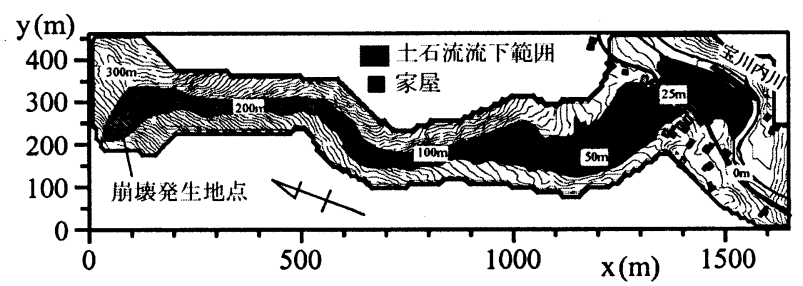

図-1 水俣市集地区の地形図と土石流の流下範囲 


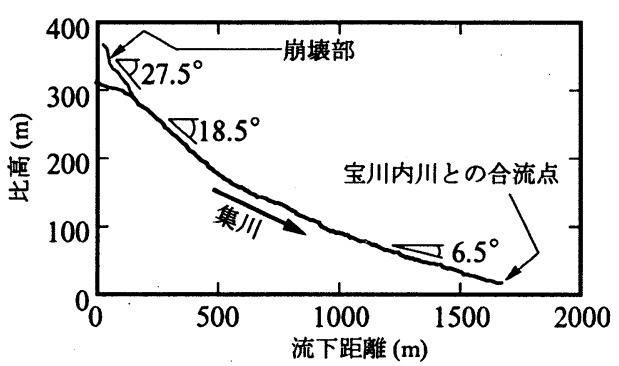

図-2 集川の縦断河床形状

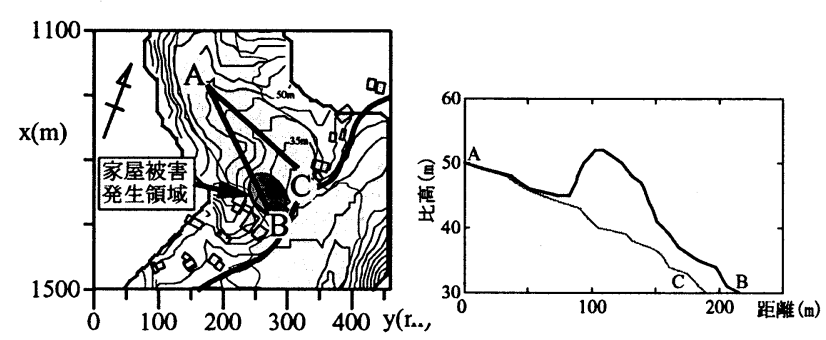

図-3土石流の氾濫範囲と河床縦断形状

図-2に土石流が流下した集川（あつまりがわ）の繸断 形状を示す。集地区は集川の扇状地上に形成された集落 であり，集川は集地区を横切り宝川内川に合流している。 崩壊発生地点の河床勾配は18度以上あり, 土石流が発生 しうる勾配である。集地区付近でも河床勾配は6度以上 あることがわかる。

図-3に集地区における土石流の氾濫範囲と河床縦断形 状とを示している。土石流発生以前は流れは地点Aから 地点Cへ流れていたと考えられるが，土石流は $10 \mathrm{~m}$ 近い起 伏を乗り越え, 地点Aから地点Bに向かって直線的に流下 し, 多数の家屋を破壊した。

7月末に行った現地調查によると, 図-3の地点Aから地 点到かけて激しい流れが作用した痕跡が数多く残され ていた。また, 崩壊発生地点の対岸は表土が剥ぎ取られ, 残された樹木は下流へとなぎ倒されていたことから，山 腹崩壊によって発生した土塊は，天然ダムを形成するこ となく直接土石流化したと考えられる。土石流は河道湾 曲部で大きく外岸に乗り上げながら周辺の表土を巻き込 み，巨砂や流木を取り込みながら流下し，集落を襲った のであろう。土石流の発生が深夜であったことと，発生 した土石流の規模が住民の想像をはるかに超えるもので あったことが被害を大きくした原因と考えられる。

\section{2 次元ハイブリッド土石流モデルによる再現 計算}

\section{(1) モデルの概要}

斜面崩壊土砂の土石流化に関する従来の研究3)による と, 山腹崩壊によって発生した土塊はいくつかのブロッ クに分かれ，流動層の上に乗った状態で流下する。土塊 の上部は不飽和土，下部は飽和土で構成される。飽和土
の部分はせん断を受けて侵食され，侵食された土砂と水 の混合物が流動層を形成する。斜面崩壊土砂の到達範囲 を知るためには，不飽和土の剛体的な運動を追跡し，か つ, 流動化した材料の連続体的な運動をも解析する必要 があるので, 有限差分法による土石流の汇濫モデルと, 土塊の運動をラグランジュ的に解析する手法とを組み合 わせることにより，2次元ハイブリッド土石流モデルが 構築された。

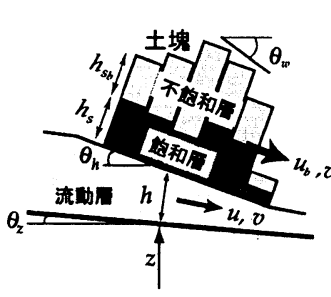

側面図

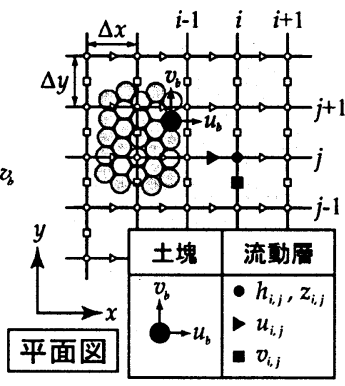

図-4 円柱ブロックと土石流計算格子の模式図
図-4に示すように土塊は複数の円柱の集合体によって 構成されているものと考え, 以下のような条件を設定し ている。

・各円柱ブロックの上部は不飽和層で下部は飽和層。

・せん断に伴い飽和層は侵食される。

・侵食された土砂は円柱ブロックと河床面との間に流動 層（土石流）を形成する。

・土石流の濃度は飽和層の濃度に等しく, 変化しない。

・流動層と土塊の間には速度差に基づくせん断力が働く。 -土塊と河床面との間に流動層が存在しないとき, 土塊 底面には動摩擦が作用する。

・各円柱ブロックの間には, 互いの距離と相対的な移動 方向に応じて引力 (or 斥力) と摩擦力が作用する.

・個々の円柱ブロックの運動は, 底面に働く摩擦力と重 力およびブロック間の相互作用とによって決定される。

なお，本研究においては土石流による河床の侵食や堆 積は考えていない。ただし, 円柱ブロックの速度が十分 に遅くなった場合には，土塊は河床と一体化したものと みなし，円柱ブロックの高さを0として，それに見合う 分だけ河床位を上昇させている。

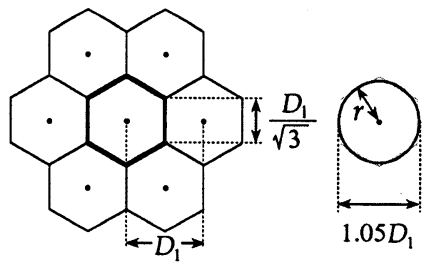

図-5 円柱ブロックの配置

（2）円柱ブロックの運動

図-5に示すように，六方最密に配置されている円柱状 のブロックによって崩壊土塊が構成されているとき，初 
期状態における各円柱ブロックの中心間の距離を $D_{1}$ と すると，ひとつの円柱ブロックが支配するエリアは，一 辺の長さが $D_{1} / \sqrt{3}$ の正六角形となる。複数の円柱ブ ロックの体積の合計を崩壊土塊全体の体積と等しくさせ るために，円柱の直径は約 $1.05 D_{1}$ としている。

円柱下部の飽和層の厚さ $h_{s}$ と上部の不飽和層（飽和 度 $s_{b}$ ）の厚さを $h_{s b}$ とすると, 円柱の質量 $M_{b}$ は,

$$
M_{b}=\rho_{T} S_{0}\left(\alpha_{1} h_{s b}+h_{s}\right)
$$

と表される。ただし, 飽和層と不飽和層の土砂濃度は等 しいと考えている。ここに， $\rho_{T}$ : 飽和層の密度であり， 係数 $\alpha_{1}$ は不飽和であることによる密度の差を表し, 次 のように表される。

$$
\alpha_{1}=\frac{C \sigma+(1-C) \rho s_{b}}{C \sigma+(1-C) \rho}
$$

2 次元的な場における各円柱ブロックの運動方程式は 次のように表される。

$$
\begin{aligned}
& \frac{\partial u_{b}}{\partial t}=g \sin \theta_{h x}+\frac{\tau_{s x} S_{0}}{M_{b}}+\frac{1}{M_{b}}\left\{\sum f_{x}+\sum f_{s x}\right\} \\
& \frac{\partial v_{b}}{\partial t}=g \sin \theta_{h y}+\frac{\tau_{s y} S_{0}}{M_{b}}+\frac{1}{M_{b}}\left\{\sum f_{y}+\sum f_{s y}\right\}
\end{aligned}
$$

ここに, $u_{b}, v_{b}: x, y$ 方向の円柱ブロックの速度, $\theta_{h x}, \theta_{h y}$ ：（流動層が存在しないときには河床勾配）， $\tau_{s x}, \tau_{s x}$ : 円柱底面に作用するせん断力の $x, y$ 方向成分, $f_{x}, f_{y}$ : 円柱間に働く引力 (or斥力) の $x, y$ 方向成分, $f_{s x}, f_{s y}$ : 円柱間に働くせん断力の $x, y$ 方向成分である。 2 つの円柱ブロックの中心間隔 $D_{b}$ に応じて 2 円柱ブ ロック間に力 $f$ が作用するものとし，その関係を図-6 のように与えている。 $D_{2}$ は引力が最大となる距離であ り，その時の引力の值 $f_{\min }$ を次のように仮定している。

$$
f_{\min }=-2 r h_{s \min } C_{b}
$$

ここに, $h_{s \min }: 2 つ$ つ柱高さのうち小さい方の值, $C_{b}:$ 粘着力である。

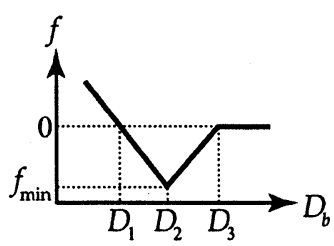

図-6 円柱ブロック間の相互作用

2 つの円柱の間に働くせん断力 $f_{s}$ は次のようである。 ( $f>0$ のとき)

$$
f_{s}=f \tan \phi+2 r h_{s \min } C_{b}
$$

( $f \leq 0$ のとき $)$

$$
f_{s}=2 r h_{s \min } C_{b}
$$

式(3) の $f_{x}, f_{s x}$ と式(4)の $f_{y}, f_{s y}$ は, $f$ と $f_{s}$ ならび に2円柱の中心座標と相対速度加計算される。

円柱底面に作用するせん断力に関しては，流動層が存 在するか否かによって異なる与え方をする。流動層が存 在する場合には, 後述する式(19)〜式(22)を用い, 存在 しない場合には河床面とブロック底面との間に動摩擦が 㗢くものとして,

$$
\begin{gathered}
\tau_{s x}=-\mu_{m} \frac{M_{b}}{S_{0}} g \cos \theta_{z x} \frac{u_{b}}{\left|u_{b}\right|} \\
\tau_{s y}=-\mu_{m} \frac{M_{b}}{S_{0}} g \cos \theta_{z y} \frac{v_{b}}{\left|v_{b}\right|}
\end{gathered}
$$

としている.ここに, $\mu_{m}$ : 動摩擦係数, $\cos \theta_{z x}$, $\cos \theta_{z y}: x, y$ 方向の河床勾配である. 動摩擦の算定に は運動方向の河床勾配を求め, 速度成分に応じて $x, y$ 方向に分配するべきであるが，ここでは簡単のため式 （8）と式(9)を用いている。流動層がなくなってから土塊 が停止するまでの時間は比較的短いので, 計算結果に大 きな不合理は生じないものと考えている。

各円柱ブロックの底面に作用するせん断力を求める際 などに，図一7に示した寄与率を用いる。寄与率とは，土 石流の計算に用いられる離散化された各変数の支配領域 と各円柱ブロックとの重なりの大小により, 両者の関係 の程度を表現したものである。

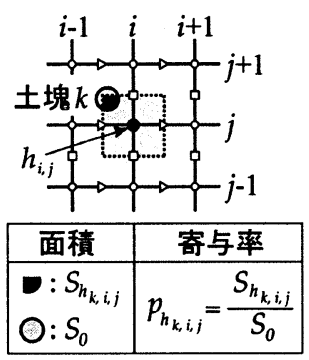

図-7 寄与率の与え方

\section{（3）流動層（土石流）の運動}

2 次元的な場における流動層の連続式は,

$$
\frac{\partial h}{\partial t}+\frac{\partial u h}{\partial x}+\frac{\partial v h}{\partial y}-i_{s}=0
$$

と表され, 流れの $x, y$ 方向の運動方程式は, 土塊の侵 食に伴う運動量輸送を無視して, それぞれ以下のように 表される。

$$
\begin{aligned}
& \frac{\partial u}{\partial t}+u \frac{\partial u}{\partial x}+v \frac{\partial u}{\partial y}=g \sin \theta_{w x}-\frac{\tau_{s x}}{\rho_{T} h}-\frac{\tau_{b x}}{\rho_{T} h} \\
& \frac{\partial v}{\partial t}+u \frac{\partial v}{\partial x}+v \frac{\partial v}{\partial y}=g \sin \theta_{w y}-\frac{\tau_{s y}}{\rho_{T} h}-\frac{\tau_{b y}}{\rho_{T} h}
\end{aligned}
$$


ここに, $h:$ 流動層の厚さ, $u, v: x, y$ 方向の流動層の 平均流速， $\tau_{s x}, \tau_{s y}$ : 土塊と流動層との間に働くせん断 力, $\tau_{b x}, \tau_{b y}$ : 河床と流動層との間に働くせん断力, $\theta_{w x}, \theta_{w y}$ : 土塊表面の $x, y$ 方向勾配， $i_{s}:$ 土塊底面の侵 食速度, $\rho_{T}$ : 流動層の密度であり,

$$
\rho_{T}=C \sigma+(1-C) \rho
$$

と表される。ここに, $C$ : 流動層の容積土砂濃度, $\sigma$ : 砂の密度, $\rho$ : 水の密度である。

河床と流動層との間に働くせん断力は, 石碩型土石流の 抵抗則を用いて，次のように表される。

( $h<30 d$ のとき)

$$
\begin{gathered}
\frac{\tau_{b x}}{\rho_{T} h}=k_{1} \frac{u \sqrt{u^{2}+v^{2}}}{h^{3}} \\
\frac{\tau_{b y}}{\rho_{T} h}=k_{1} \frac{v \sqrt{u^{2}+v^{2}}}{h^{3}} \\
k_{1}=\frac{d^{2}}{\left.8\{C+(1-C)(\rho / \sigma)\}\left(C_{*} / C\right)^{1 / 3}-1\right\}^{2}}
\end{gathered}
$$

（ $h \geq 30 d$ のとき）

$$
\begin{gathered}
\frac{\tau_{b x}}{\rho_{T} h}=g n_{m}^{2} \frac{u \sqrt{u^{2}+v^{2}}}{h^{4 / 3}} \\
\frac{\tau_{b y}}{\rho_{T} h}=g n_{m}^{2} \frac{v \sqrt{u^{2}+v^{2}}}{h^{4 / 3}}
\end{gathered}
$$

ここに, $d$ : 粒径, $C_{*}$ : 堆積層の容積土砂濃度, $n_{m}$ : マニングの粗度係数である。現時点では流動層内部の流 速分布に関する十分な知見が得られていないので，ここ では簡単のため, 従来の土石流の抵抗則を使用している。

土塊と流動層との間に働くせん断力は, 流動層と土塊 との相対速度を考慮して次のように表している。

( $h<30 d$ のとき)

$$
\begin{gathered}
\frac{\tau_{s x}}{\rho_{T} h}=k_{1} \frac{\left(u-u_{b}\right) \sqrt{\left(u-u_{b}\right)^{2}+\left(v-v_{b}\right)^{2}}}{h^{3}} \\
\frac{\tau_{s y}}{\rho_{T} h}=k_{1} \frac{\left(v-v_{b}\right) \sqrt{\left(u-u_{b}\right)^{2}+\left(v-v_{b}\right)^{2}}}{h^{3}}
\end{gathered}
$$

( $h \geq 30 d$ のとき $)$

$$
\begin{aligned}
& \frac{\tau_{s x}}{\rho_{T} h}=g n_{m}^{2} \frac{\left(u-u_{b}\right) \sqrt{\left(u-u_{b}\right)^{2}+\left(v-v_{b}\right)^{2}}}{h^{4 / 3}} \\
& \frac{\tau_{s y}}{\rho_{T} h}=g n_{m}^{2} \frac{\left(v-v_{b}\right) \sqrt{\left(u-u_{b}\right)^{2}+\left(v-v_{b}\right)^{2}}}{h^{4 / 3}}
\end{aligned}
$$

侵食速度に関しては円柱ブロックごとに次式により計 算し，図一7の寄与率を用いて平均化している。なお，侵 食速度は土塊の物性に応じて決まるものであると考えら
れるが，現時点で十分な知見は得られていないので便宜 的にこの式を用いている。

$$
i_{s}=\beta \sqrt{\left(u-u_{b}\right)^{2}+\left(v-v_{b}\right)^{2}}
$$

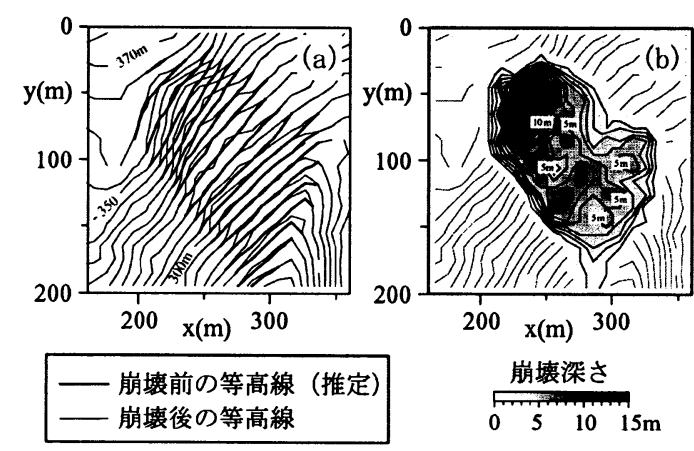

図-8 斜面崩壊の形状

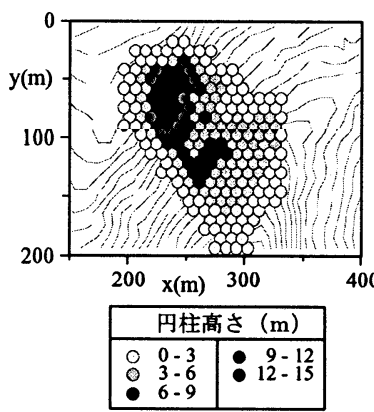

図-9 円柱ブロックの初期配置と初期形状

\section{（4）計算条件}

崩壊の形状については，図-8(a)に示すように崩壊前 の地形を周辺地形から推定し, 崩壊後の形状との比較に より, 崩壊深さの平面分布を求めた (図-8 (b))。崩壊 土砂量は6.75万立方メートルとなり, 砂防学会調查団の 速報による「5万から10万立方メートル」と合致する。 崩壊深さの平面分布をもとに円柱ブロックの初期高さを 求めている (図-9参照)。

土石流の計算グリッドの大きさは $x, y$ 方向ともに $10 \mathrm{~m}$, 計算の時間ステップは0.05秒である. 円柱ブロック底面 の半径は $4.85 \mathrm{~m}$, 円柱ブロックの初期中心間隔 $D_{1}$ は $9.24 \mathrm{~m}, D_{2}$ は $9.70 \mathrm{~cm}, D_{3}$ は $10.16 \mathrm{~m}$ とした。崩壊土砂や 流動層の土砂濃度は 0.5 , 土塊の不飽和部分の不飽和度 は 0.3 , 粒径は $10 \mathrm{~cm}$, マニングの粗度係数は 0.04 , 土粒 子の比重は2. 65, 土塊と河床面との間の動摩擦係数 $\mu_{m}$ は0.5, 土砂の内部摩擦角 $\phi$ は $30^{\circ}$, 土砂の粘着力 $C_{b}$ は 179Pa としている。粘着力は土塊ブロックが一団となっ て流下するように試行錯誤的に決定した。

Case 1では初期状態において崩壊土砂がすでに土石流 化していたものと考え，土塊の高さはすべて0とする代 わりに，初期状態における崩壊箇所の流動深を図-8 (b) のように与えた。

Case 2では初期流動染としては微小值 $(5 \mathrm{~mm})$ を与え, 土塊の初期高さとして図-9のように与えている。崩壊土 砂はすべて飽和度で構成されているものとし, 侵食速度 の係数 $\beta$ は 0.12 としている。

Case 3シリーズにおいても土塊の初期高さは図-9のよ 


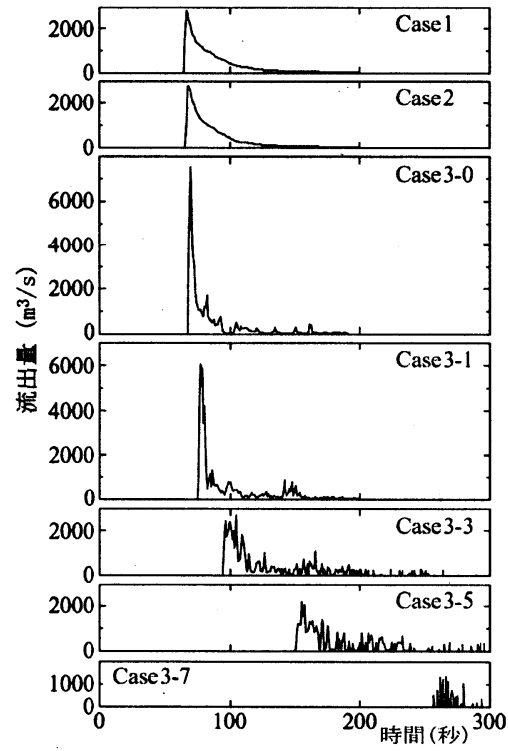

図-10 流出土砂量の時間的変動 $(x=900 \mathrm{~m})$

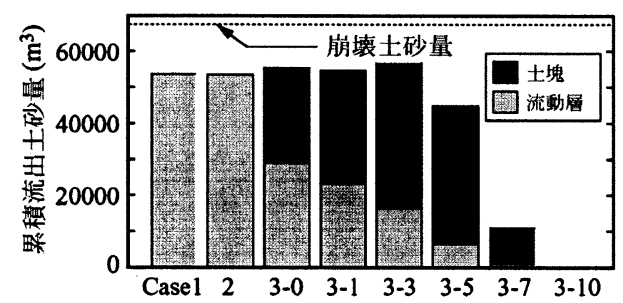

図-11 $x=900 \mathrm{~m}$ の断面における累積流出土砂量
うに与えている。侵食速度の係数 $\beta$ はいずれも 0.012 と し, 不飽和層の厚さのみを変化させている。Case 3-0で は不飽和層の厚さは0m, Case 3-1では1mであり, Case番 号の最後の数字が不飽和層の厚さ $(\mathrm{m})$ を示している。土 塊ブロックの高さが不飽和層厚さの設定値より小さい場 合には，そのブロック全体が不飽和土で構成されている ものとする。

計算時間はCase 1 とCase 2 とCase 3-0 とCase 3-1は 200秒であり，それ以外は300秒である。

\section{(5) 計算結果と考察}

図-10には， $x=900 \mathrm{~m}$ の断面における流出土砂量の時間 的変化が，崩壊発生時を0として示されている。 $x=900 \mathrm{~m}$ の断面を通過する流動層のフラックスと土塊ブロックの 体積を計算ステップごとに累積值として記録し，1秒ご との累積值の増加量を基に流量を求めた。図-11には各 ケースにおける計算終了時までの累積流出土砂量とその 内訳が示されている。これらを見ると, Case 1とCase 2 はほぼ似通った結果となっていることがわかる。Case 2 では侵食速度が大きいので, 崩壊発生後比較的短時間に すべての土塊が流動化し，瞬時に土塊が流動化したと考 えたCase 1と同様の結果になったものと思われる。比較 的ゆっくりと土塊が流動化した場合に相当するCase 3-0 では, $x=900 \mathrm{~m}$ の断面を通過する時点で約半量の崩壊土 が流動化しないまま残っており，それが土石流の先頭部 付近に集中して流れたためにピーク流量がCase 1の2倍 以上の值となっている。また, Case 3のシリーズを比較 することにより, 不飽和土の割合が大きくなるほど, 土 石流の到着時間は遅くなり, ピーク流量も小さくなるこ とが分かる。

図-12には各ケースにおける流動梁と土塊高さの平面 分布が示されている。また，図-13には計算終了時にお
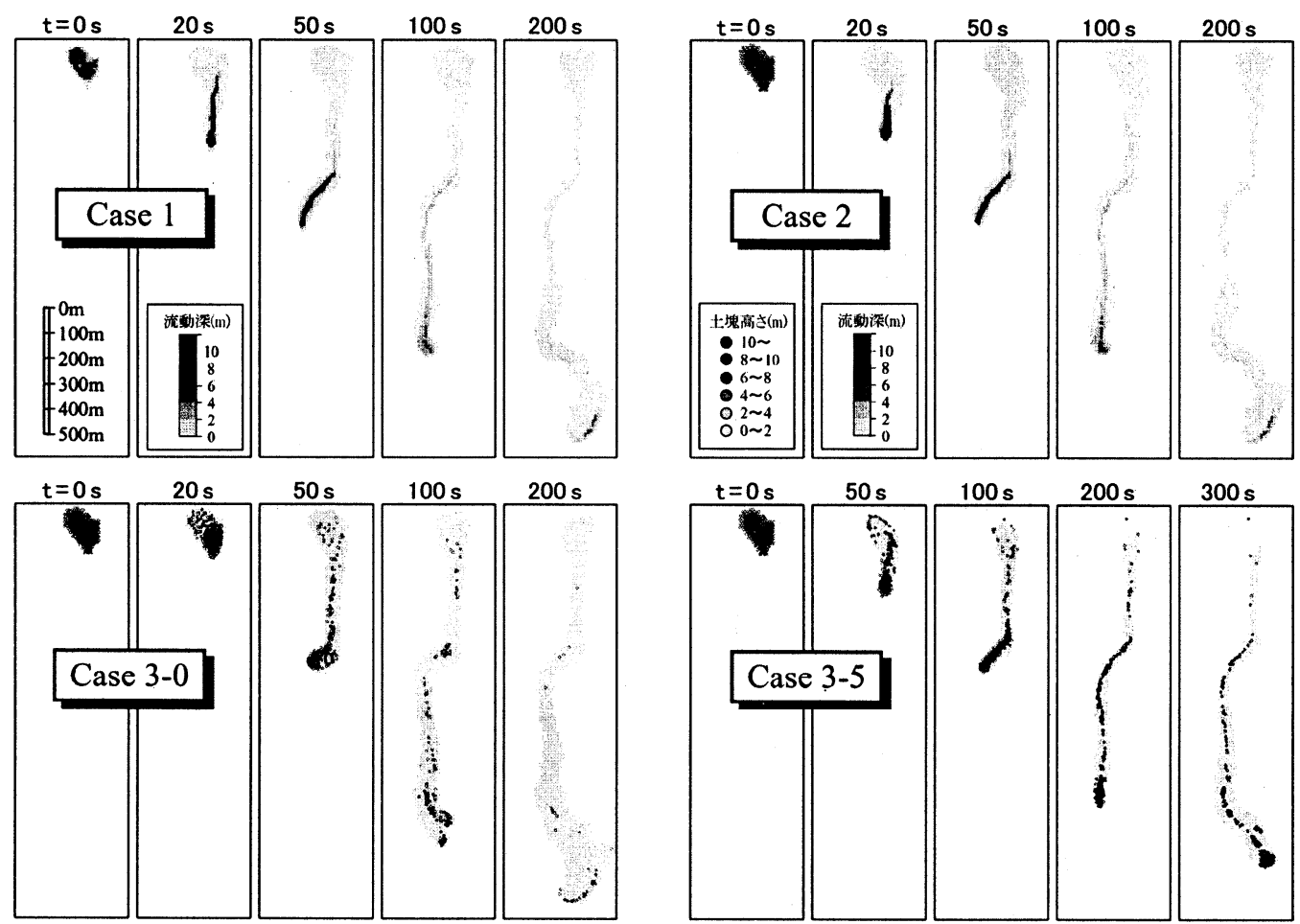

図-12 流動深と土塊高さの平面分布 

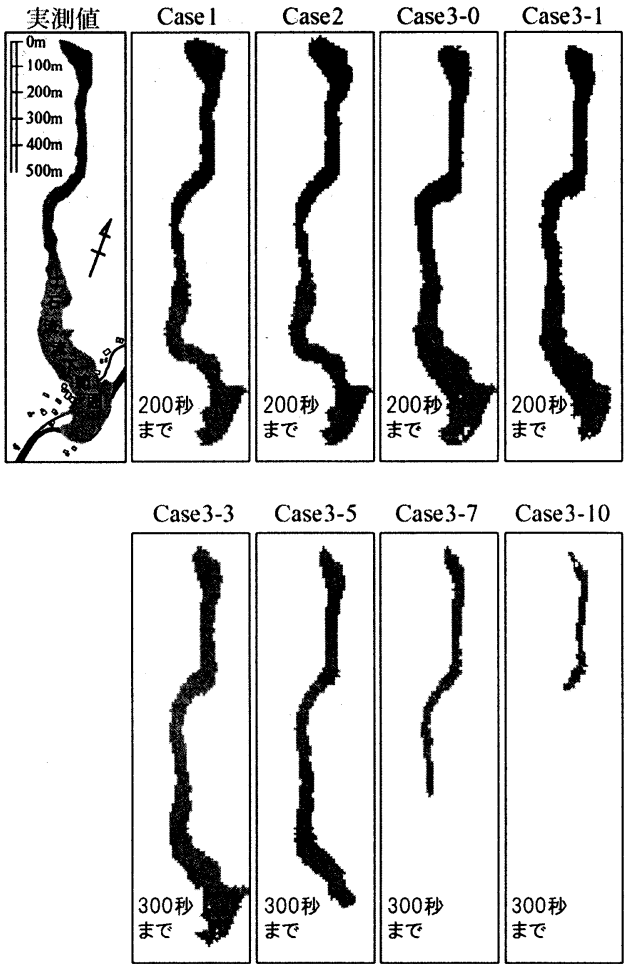

図-13 土石流の流下範囲

ける土石流の流下範囲を示している。前述のように, Case 2では崩壊発生後20秒以前にすべての土塊は流動化 しており，その後の流下過程はCase 1とほとんど同じで ある。これらのケースでは，図-3に示された地点Aから 地点Bへ向かう流れは発生せず，地形に沿って地点Aから 地点Cへと土石流は流れている。これに対し, Case 3-0 やCase 3-1では流量が大きいため, 地点Aから地点Bへ直 線的に向かう流れと, 地点Aから地点C一向かう地形に 沿った流れの両方が認められた。Case 3-0とCase 3-1の 土石流流下範囲に関する計算結果は実測值を良好に再現 できているといえる。

土塊の不飽和部分が大きい場合, 不飽和部は流動化し ないと考えているため, 飽和層を失った土塊は河床面と 摩擦を生じて減速し，やがては停止して河床と一体化す る。図-14にはCase 3-10における河床上昇量（堆積量） の平面分布が示されている。これを見ると，崩壊土の大 部分は $x=500 \mathrm{~m}$ より上流側に堆積し, 天然ダム状の地形 が形成されていることがわかる。

\section{4. おわりに}

本論文では平成15年7月に水俣市で発生した土石流災 害に対して2次元ハイブリッド土石流モデルを適用し，

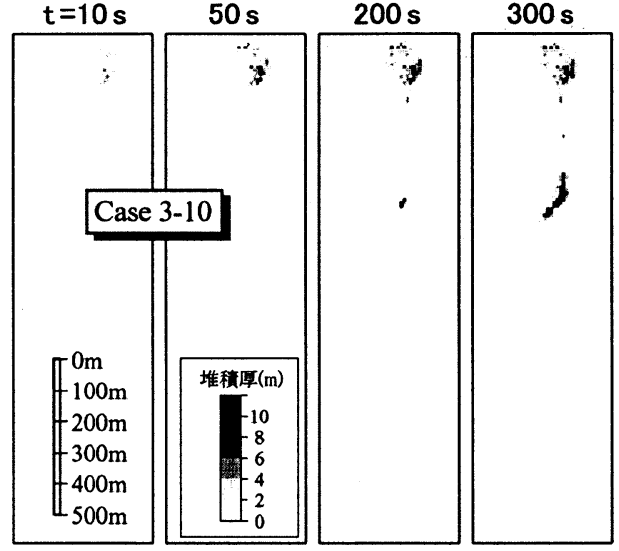

図-14 河床上昇量の空間分布

崩壊土砂が流動化しながら谷を流下する過程を再現した。 土塊が流動化する速さを種々変化させて計算を行った ところ, 崩壊発生直後に崩壊土砂が流動化する場合に比 べ，比較的ゆっくりと土塊の流動化が進む場合のほうが ピーク流量は大きくなり，氾濫範囲も実測值に近くなる ことが判明した。

また, 崩壊土砂の不飽和部分が大きい（流動化しない 部分が大きい）場合には, 崩壊土砂は河道上に堆積し,

天然ダムを形成することがわかった。

本研究では流動層の堆積や侵食を考慮していないため, 土石流が側岸や河床から土砂を取り込み, その流量が増 大してゆくことは再現できていない。また，土石流が直 線的に流下して集落を襲った原因に関しても，急激な土 砂の堆積によって一時的に谷が埋め尽くされた可能性も 考えられる。今後, こういった点に関して改良してゆく 必要があると考えている。

\section{参考文献}

1) 中川 一・高橋 保・里深好文・立川康人 - 市川 温 - 吉田 義則・ 中村行雄 : 平成 9 年鹿児島県出水市針原川で発生した 土石流災害について, 京都大学防災研究所年報, 第 41 号 $\mathrm{B}-2$, pp287-298, 1998.

2) 山田 孝・南 哲行・小山内信智・水野秀明 : 1997年7月 10 日に鹿児島県針原川で深層崩壊に起因して発生した土石流の 流下 - 堆積状況, 砂防学会誌, Vol. 51, No. 1, pp. 46-54, 1998.

3) 里深好文・高橋 保 : 斜面崩壊を起因とする土石流に関する 数值シミュレ ション，水工学論文集，第 47 巻，pp. 583 588, 2003.

(2003. 9. 30受付) 